Alma Mater Studiorum - Università di Bologna DEPARTMENT OF ECONOMICS

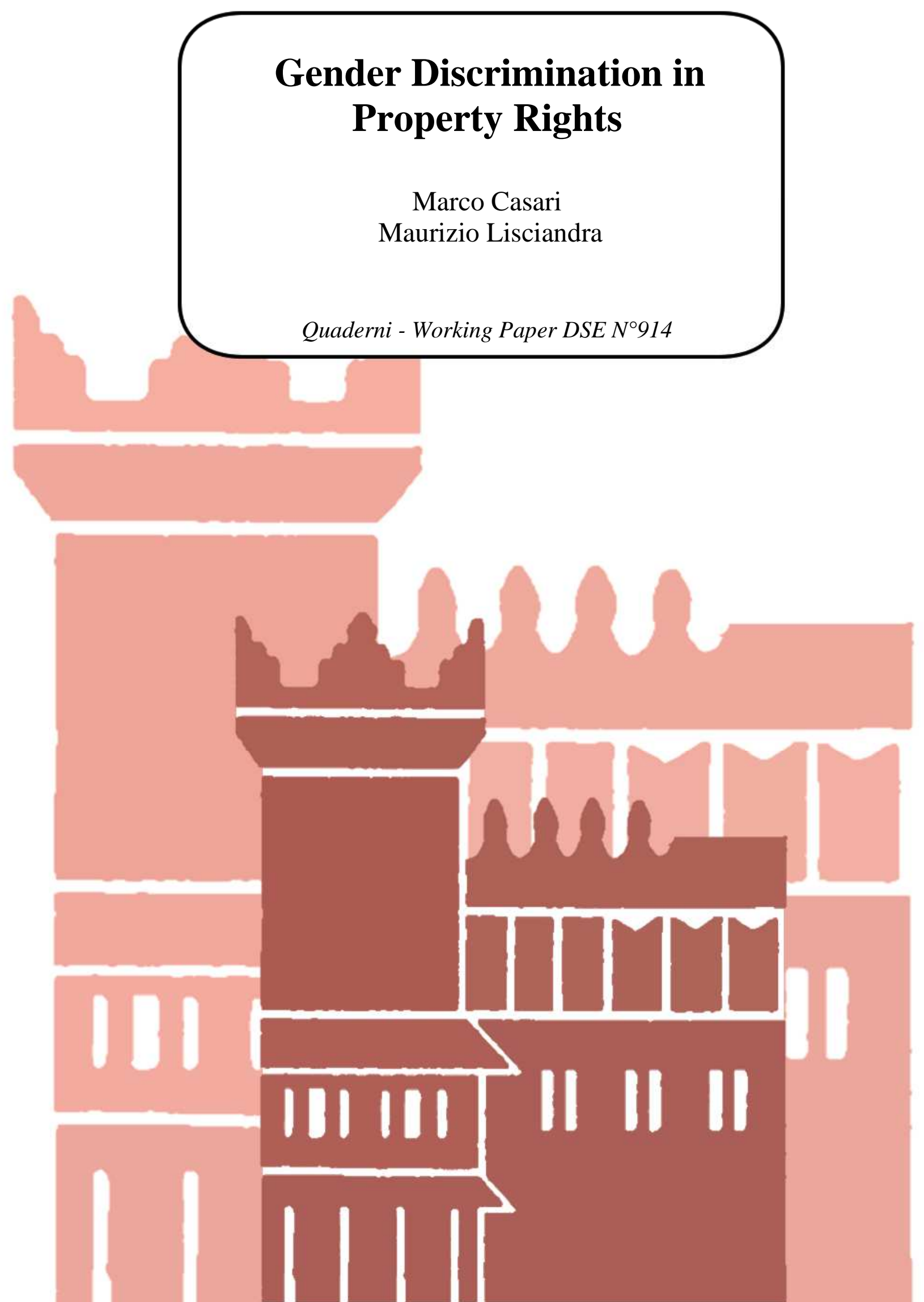




\title{
Gender Discrimination in Property Rights
}

\author{
Marco Casari \\ University of Bologna \\ and \\ Maurizio Lisciandra \\ University of Messina *
}

26 November 2013

\begin{abstract}
In the Middle Ages women in the Italian Alps had substantially more rights on collective properties than in the Modern Age. The documental evidence shows a progressive erosion of women's rights and a convergence toward gender-biased inheritance systems. We tracked the evolution of inheritance regulations on collective land in the peasant communities of Trentino over a period of six centuries (13th-19th). Considering a panel of hundreds of communities, we provide a long-term perspective of institutional change. When population pressure increased, a patrilineal system emerged as a protective measure to preserve the per-capita endowment of collective properties within a community. This study raises general issues about the role of local level versus centralized decision-making in delivering gender equality and about the long-term trade-off between the protection of common resources and a healthy genetic pool at the community level.
\end{abstract}

Keywords: long-term institutional change; land rights; endogamy; migrations; common property. JEL: J16; N53; Q20.

\footnotetext{
* M. Casari: University of Bologna. Department of Economics, Piazza Scaravilli 2, 40126 Bologna, Italy. Phone: +39 051 209 8662, email: marco.casari @ unibo.it (corresponding author); M. Lisciandra: University of Messina. Department of Economics, Business, Environmental and Quantitative Methods, Piazza Pugliatti 1, 98122 Messina, Italy. Phone: +39 090 641 1070, email: mlisciandra@ unime.it. We thank the following for their comments- Benito Arruñada, Guido Alfani, Dari Mattiacci, Tine De Moor, and the seminar participants at the University of Amsterdam, University of Utrecht, Italian Society of Law and Economics Meeting in Bologna, University of Valencia, the Bozen workshop on property rights, the German Law and Economics Meeting in Bozen, the Nonantola workshop on Italian commons, the Italian Economic Association Meeting in Bologna. The usual disclaimer applies.
} 


\section{Introduction}

In many societies women are discriminated against in economic and in social life. Besides cultural reasons, discriminatory practices and beliefs may also be rooted in economic grounds, where gender roles developed as a consequence of specific production technologies (e.g., Engels, 1884). We contribute to the economic explanations of gender discrimination by focusing on the discrimination in property rights. In particular, we study the structure of property rights on the common pastures and forests of hundreds of small peasant communities in the Italian Alps from the late medieval to the early contemporary period (i.e., $13^{\text {th }}-19^{\text {th }}$ century). What emerged from a systematic analysis of the original documents is a clear trend of erosion in women's rights. While in the XIII century women enjoyed extended or little compressed rights on the land of the community, with the advent of the modern period at the end of the XV century their rights became gradually weaker. By the end of the XVIII century the process in these alpine communities was already complete: inheritance of the collective properties was nearly everywhere patrilineal.

We argue that the patrilineal system was preferred to the egalitarian one because it better protected the community resources from outside immigration. This pattern of institutional changes raises two general issues. First, the autonomous decisions at the community level brought about gender-biased inheritance systems that were evolutionarily stable. Left alone under decentralized decision-making, communities engaged in a progressive closure to outsiders. Once the process was completed, the communities remained locked into a situation of women's discrimination; only a centralized political regime could change this course of action. Second, gender-biased inheritance systems closed the communities to outsiders and this had a negative impact on the genetic heritage because of increased endogamy levels. Communities, therefore, faced a trade-off between the protection of common resources and a healthy genetic pool.

The inheritance system of the commons is a cornerstone of the ecological and demographic balance of traditional peasant societies (Cole and Wolf, 1974). The ecological balance can be compromised when the commons are overexploited (McNetting, 1981). Such overexploitation is known as "the tragedy of the commons", which can occur in a one-shot interaction within a given group of users (Hardin, 1968). To widen the perspective, one has to consider settings where the interaction is repeated over time and where the size of the group of users is endogenous. Interestingly, inheritance systems play an important role in determining group size because they shape the incentives for migrations and fertility. We focus on migration because it can modify group size more quickly than changes in fertility rates. Thus, migration flows can trigger defensive measures and consequently institutional change at the community level.

Over time, Trentino communities developed formal protective measures to limit the overexploitation of the common land in the form of community statutes (Casari, 2007). A community that was rich in terms of common land was challenged by outsiders attempting to appropriate the resource. The most immediate form of appropriation was trespassing, which was avoided by establishing property rights on the community land through the demarcation of land borders, the establishment of legal rights, and the hiring of guards to patrol the land. Once the resource was no longer open-access, opportunistic 
behavior over the commons could still occur in other ways. Outsiders could move in, settle down in the community and claim the use of common land and resources. To prevent all residents from accessing the commons, insiders entitled only the original members of the community with a special legal status, called membership right, which granted the full belonging to the community in terms of rights and duties. These types of regulations and entitlements were widespread in many areas of Europe (Ostrom, 1990, De Moor, 2008 and 2009, Alfani, 2011). However, by marrying a member of the community outsiders could still gain access to the commons, and their descendants. This would effectively and permanently increase the size of the group. Hence, here is where the inheritance system intervened. Under an egalitarian inheritance system, in which both men and women enjoyed membership rights, outsiders from poor communities could enter a rich community by marrying an insider. This had distributional consequences on the rich community as it contributed to depleting the per-capita amount of community resources. On the contrary, a patrilineal inheritance system discouraged outsider men to marry insider women, in this way keeping under control the net migration in the community.

This research presents three qualifying aspects. First, it considers institutional change over a very long time span, which enables us to capture deep forces that shape human societies. Without this long-run perspective, the patterns of inheritance change may have gone unnoticed. ${ }^{1}$ Second, this investigation is not a single-case study but a panel of cases consisting of hundreds of communities in the alpine region of Trentino. Each community could autonomously regulate inheritance. This provided a unique natural experiment because communities could adopt a variety of inheritance rules. One can exploit systematic variations across communities to infer the drives of institutional change. Third, we observe that gender discrimination in property rights became more severe with the approach of the modern period; this provides the opportunity to study economic factors behind the process of women's rights erosion.

The structure of the paper is the following. Section 2 introduces the study and the property rights structure in Trentino. Section 3 presents the data sources and the institutional evidence. Section 4 puts forward our interpretation of the evidence. The empirical evidence is presented in section 5, which includes a static and a dynamic econometric model illustrating the institutional change. Section 6 discusses some related issues; finally, section 7 puts forth our conclusions.

\section{Property rights in Trentino from 1200 to 1800}

\subsection{The historical setting}

Trentino is a mountainous region in Northern Italy with a few hundred very small villages scattered over an area of about 6,200 square kilometers. According to the 1810 census, the median village population was 394. Figure 1 shows the shares in terms of surfaces of the land ownership according to land type in a selected sample of villages. Collective land was largely predominant in the forests and grazing lands. On the contrary, plow land and vineyards were mainly individual property, although some arable land could also be under a commons regime. Finally, about $25 \%$ of meadows were

\footnotetext{
${ }^{1}$ Similarly, Botticini and Siow (2003) provide a long-run perspective based on systematic data collection on dowry practices in Medieval and Early Renaissance Tuscany.
} 
collective. Forests were a precious source of firewood, timber, craft furniture, and underbrush material used as bedding for animals. Meadows and pastures were necessary for cattle grazing and consequently for the production of dairy products. The commons were not open access resources, to wit, available for everyone to use. Instead, they were collective property of a well-defined group of individuals living in the same village or group of villages with legal entitlement to use the resources. Consider that less than $10 \%$ of the entire region was cultivable. See also Casari (2007) for a general description.

\section{Figure 1. Land ownership by land type (surface)}

(A) Forests

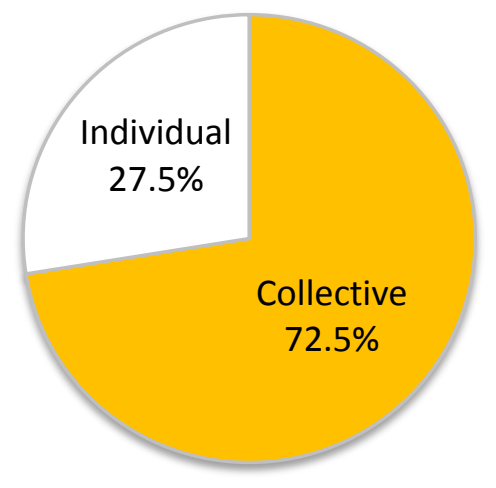

(B) Meadows

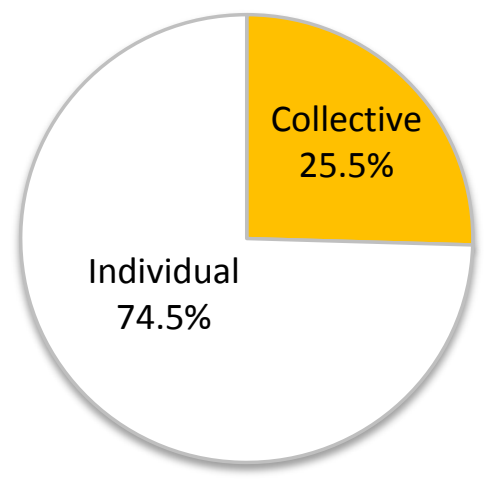

(C) Plow land and Vineyards

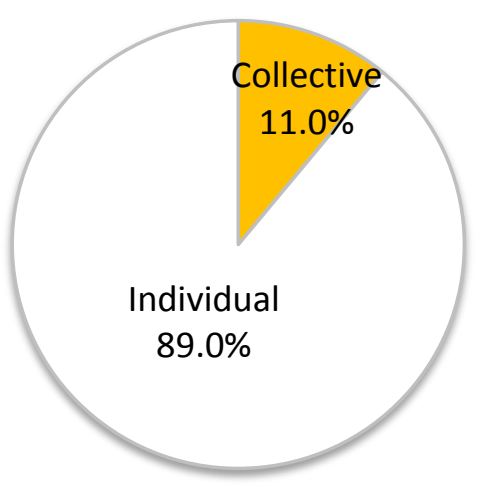

Source: 1780 cadastral registers.

Notes: data about a sub-sample comprising 32 villages (about $10 \%$ of the total). (A) It also includes grazing land and alps; (B) meadows of one and double sawing at low altitudes; (C) also includes orchards and vegetable gardens. The 1780 cadastral register offers the first systematic land survey in this region and reports detailed data on both the rent and the surface of the various types of land (e.g., meadows, forests, etc.). In addition, it contains data on land ownership (e.g., individual versus collective), by village and land type.

The Prince-Bishops of Trento ruled over the region for almost eight centuries: from 1027 until 1796. From the XIII century, the communities of Trentino gradually started to codify a set of rules for the management of their resources in formal documents, called charters (carte di regola). Charters were official deeds engrossed by a notary in the presence of external witnesses, and subsequently confirmed by the Prince, who granted self-government on the commons and other local economic affairs, and certified that the charter was compatible with the existing laws. Such documents regulated $(i)$ the right to establish appropriation rules of the collective resources, (ii) the right to hold community assemblies and appoint a governor (regolano) and other community officials, (iii) the right to locally enforce the appropriation rules by levying cash fines, and $(i v)$ the protection of community resources from external encroachment. Charters defined the geographical entities which, for clarity purposes, we call "communities" whereas, we shall call "villages" the geographical units of cadastral registers. A charter with a special status was the statute of Trento, the capital town, which provided for supplemental discipline on issues that were missing in other community charters. 
Self-government could take place over different territorial levels. Overall, we considered 264 communities that adopted a charter, ${ }^{2}$ which were organized in one of the following four ways: a) 31 "supra-communities," which grouped and regulated a few connected villages, of which at least one had, at the same time, a local charter; b) 97 "connected communities," which, at the same time, had their own local charter and were within a supra-community; c) 131 "standalone communities," which had their own charter and were unconnected to any supra-community; d) 5 "special communities," commonly called vicinie, consisting of a few families within a village or families belonging to different villages jointly exploiting some portions of forests and pastures. Charters of special communities could be in force side by side in the same village(s) with charters of community types $a$ ), $b$ ), and $c$ ).

The community of Civezzano was the first to write a charter in 1202. The charter system collapsed because of an exogenous political shock at the very beginning of $19^{\text {th }}$ century. Napoleon suspended the system after invading the region in 1796, then definitively abolished it in $1807 .^{3}$ The most ancient charters did not provide a systematic discipline of all aspects of community life and management of the common resources. Occasionally, community rules were updated by means of new chapters within an existing charter, or by enacting an entirely new charter. The charters appear as pragmatic instruments adopted by uneducated peasants revolving around actual litigation cases. They reflected specific responses to external challenges or contingent problems, which can be noticed in the sequence of isolated tweaks to the rules produced in some communities, often listed as additions to a pre-existing charter. Thus, we argue that charters summarized in writing the way a community resolved critical controversies arisen in the past. If an issue was not present in a charter, most likely it had not been a controversial matter in the community. We will rely on this general interpretation rule also when discussing inheritance systems.

\subsection{Rights to access collective resources}

Access to the collective resources and participation in the community life could take place at different levels and this section provides a taxonomy. The focus in this paper will be on the membership right (vicinia), which defined the most complete belonging to a community. We refer to those with membership rights as "community members" (vicini) or "insiders." The family was the unit of reference for membership rights. If husband and wife were both community members, they were entitled to the same benefits and duties as if only one spouse was a member. If at least one living individual of the family was a community member, then the benefits from the commons were extended to all relatives living under the same hearthstone (fuoco). The head of the family, who was usually although not necessarily - the rights-holder, was the person with the rights to participate in and vote at community meetings. People without membership rights were "outsiders," a category that includes also those with the simple right to reside in the community, or with some right to appropriate the commons.

\footnotetext{
${ }^{2}$ For 229 communities, at least one charter was available. There were further 10 communities with other relevant documents for the investigation but no information about a charter. There also existed statutes, different from charters, that encompassed many villages and regulated especially criminal justice (e.g., Val di Sole e Non and Valle delle Giudicarie).

${ }^{3}$ In 1802 the Paris Treaty abolished the bishop principality of Trento. The Austrian government in 1805 forbad the gatherings of the community members in the assemblies, and in 1807 the Bavarian government, which in the meanwhile took power in Trentino through the peace of Presbourg (1805), abolished the Carte di Regola and subjected Trentino towns and villages to the central government.
} 
To a certain extent, all definitions in this section are conventional, and we introduce them to better interpret the content of the charters. ${ }^{4}$ See also Casari and Lisciandra (2011) for additional details.

The membership right gave full access to all benefits and duties. An insider enjoyed four categories of rights: $(i)$ residence rights - the right to live in the community and thus have a stable domicile; (ii) full appropriation rights - the right to access and exploit the common resources of the community; (iii) participation and voting rights in community assemblies, in particular, rights to participate and speak at community assemblies, to appoint community officers, and to vote on decisions concerning management and alienation of collective resources, inheritance systems, acquisition of residence, appropriation, and membership rights; finally, (iv) inheritance rights, and more specifically the right to transmit the membership to offspring according to regulations. ${ }^{5}$

Sometimes, outsiders could live in the community with limited or no rights to access the commons. The most common entitlements were the appropriation right and the residence right. The appropriation right entailed residing in the community and granted some or all of the following entitlements: grazing, mowing grass, cutting timber, collecting firewood and litter, hunting and fishing, and transforming forests or pastures into arable land. Individuals could not pass appropriation rights on to descendants through inheritance. Conversely, the simple residence right did not per se entitle the right-holder to use the collective resources. In order to acquire the residence right, outsiders often had to formally introduce themselves to the community and give assurance about their integrity and economic welfare. Typically, residence rights were granted to artisans, shopkeepers, and servants. Fines and restrictions for trespassing collective lands or using collective resources without authorization applied also to those with residence rights. Finally, rule violations could cause the loss of that right.

\subsection{How to acquire the membership right}

There were three ways to acquire the membership right: by purchase, by inheritance from partners, and by inheritance from parents.

Purchase. The membership right could be purchased from the community. It could not be purchased from an individual insider because a single member of the community could not transfer or alienate his or her individual membership right. The community assembly had to grant its formal consent in order to accept new members with a vote requiring a quorum ranging from a simple majority of half of the participants up to unanimity. Generally, outsiders had also to fulfill a few requirements such as $i$ ) having a good reputation, ii) paying the community treasury a certain amount of money, and iii) having

\footnotetext{
${ }^{4}$ The aim of this study is neither to provide a legal classification of rights nor to map in detail all cases. On the contrary, we aim at analyzing the documents through a parsimonious taxonomy, which reflects economic property rights, that is those rights that an individual can actually exploit no matter what the formal or legal definitions are.

${ }^{5}$ Membership in the medieval Trentino communities presents similarities to citizenship in contemporary national states, yet there are at least three noteworthy differences. First, it was more pervasive in terms of rights as well as duties. Fundamental duty was a continuous residence within the community. Moreover, members had to collaborate to build and maintain roads, huts, kilns, and wood coal sites. Refusal to fulfill such duties could bring about the loss of membership. Second, the rightsholder was the head of the family, the unique legal representative of the family in front of the community, although rights and duties extended to the whole family. The family was a single entity, and all families shared equal rights of access to the commons regardless of their size. Third, membership acquisition followed a different discipline with respect to modern citizenship.
} 
held stable residence in the community for a certain period of time. The membership right gave equal rights and duties to newcomers as to pre-existing members. In Trentino, we detected 54 out of 274 communities that allowed membership purchase. This provision was mainly mentioned in the community charters but it was also documented in contracts of membership purchase.

Inheritance from partner. In case of marriage between an insider and an outsider, the insider spouse kept his or her status through marriage and could sometimes pass it on to their children, as we will see below. As a consequence of the marriage, the outsider spouse could receive - depending on the community - the membership right, the appropriation right, or no right at all. Whereas, in case of marriage between two insiders, membership rights could not be cumulated since the unit of reference was the family. One spouse's membership right, typically the wife's, remained dormant while she was married and became active only with widowhood.

Inheritance from parents. The membership right became manifest when the heir left the parents to form a new family, or alternatively, at the rights-holder's death. We have identified four basic inheritance systems for collective resources from parents: egalitarian, soft-patrilineal, patrilineal, and primogeniture. These inheritance systems encompass all the systems encountered in the Trentino charters. Egalitarian: all sons and all daughters of insiders inherited the membership rights. SoftPatrilineal: all sons of insiders inherited membership rights whereas daughters did not, unless daughters had no brothers. In the latter case, one daughter or all daughters could inherit membership. If only one daughter inherited the membership, she was usually designated by the father or by the relatives; alternatively the charters usually gave the rights to the first-born or the last-born. Patrilineal: all sons of insiders inherited the membership rights whereas daughters did not, even if they had no brothers. Primogeniture: only one child of an insider family inherited the membership rights. Ordinarily the heir was a son chosen by the father's last will or, if lacking, by the closest relatives. If there was no son, or the son was not considered suitable and fit, one (and only one) daughter could inherit the membership (along with the private assets) conditionally to marrying a man, who could be an outsider. ${ }^{6}$

\section{Institutional evidence}

The evidence combines data from various sources: charters, cadastral registers, and population census. We identified a total of 480 community charters, of which 306 were available for reading. We also collected relevant information about charters modifications and other specific documents containing

\footnotetext{
${ }^{6}$ Depending on the specific regulation of the community, the appropriation rights could also be acquired in three ways: by purchase, by inheritance from a spouse, by inheritance from a parent. An individual could not sell the appropriation right but the community could grant it. The rationale of the transmission by inheritance of appropriation right was to compensate offspring or spouses who were not entitled to receive the membership right, and hence it constituted a sort of welfare system that allowed these persons to access the common resources when orphans or widows. Only insiders could transmit by inheritance the appropriation right. The orphans of insider parents could acquire the appropriation right when the membership right was denied. This was especially the case for daughters within a patrilineal system. Their appropriation right remained dormant until the death of the insider member of the family. Women who inherited appropriation rights from their parents could preserve or lose them after marriage. In general, appropriation rights ceased when entitled women married outsiders and could be preserved if they married insiders. The possible loss for widows of appropriation rights could be a very high price to be paid, thereby affecting marriage or remarriage decisions.
} 
regulations of inheritance systems of the commons, which enabled us to build a database of 879 observations. This evidence was organized around 366 villages as coded in the 1897 cadastral registers.

Figure 2 shows a map of the region with the villages that adopted a charter and some regulation of the inheritance systems of the commons in two different years of the time interval under scrutiny, 1525 and 1801. There was a steady increase in charter adoption during the first four centuries with a peak in the second half of the XVI century. In 1525, immediately before the peak, the villages that had a charter already covered an area equal to $64 \%$ of the region. Conversely, it is noteworthy that in 1525 hardly no village had formally introduced inheritance regulations over their commons within their charters or other relevant documents. In 1801, at the end of the time interval, the villages with a charter covered $84 \%$ of the Trentino surface. By 1801 many communities had enacted their second or even third charter. Inheritance regulations became more frequent with the expansion of charters adoption, but notwithstanding that, villages with a formalization of inheritance rules covered only $25 \%$ of the region.

\section{Figure 2. Mapping charters and inheritance regulations in Trentino}

1525 (Peasant war)

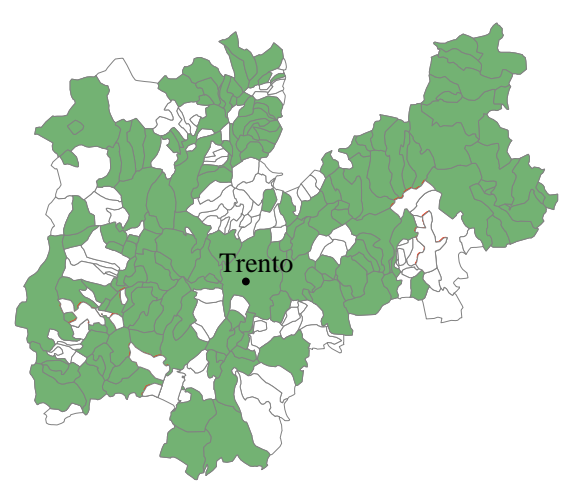

1801 (Napoleon shock)

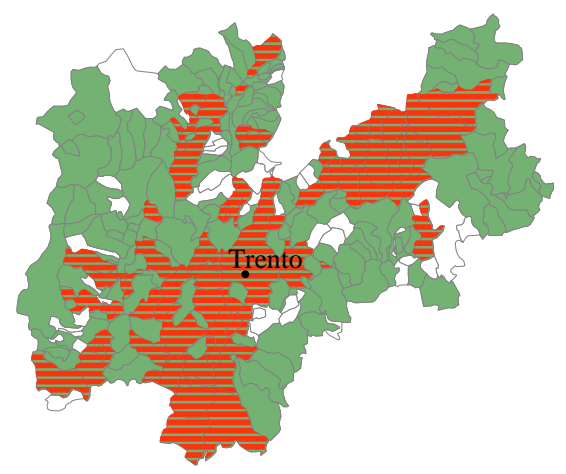

Notes: Areas with solid color identify the presence of a charter while areas with striped color identify the presence of inheritance regulations on the commons. A geographical unit in the map is colored when most of its surface satisfies the condition of having a charter and/or inheritance regulations by the dates of 1525 and 1801. Charters define the geographical entities that we call "communities." We then mapped communities into the geographical units, the "villages", of the 1897 cadastral registers. The current cadastral registers, which are the ones shown in this figure, display a coarser partition than the 1897 register.

Three main findings about inheritance systems on the commons in Trentino emerge from the documental evidence in our possession. First, inheritance systems for the transmission of membership rights on the commons changed over time. Second, almost all changes eroded women's rights to inherit collective resources. Third, the majority of the charters did not regulate inheritance of membership rights on collective resources.

During the six centuries under scrutiny, the patterns of inheritance changed substantially. Table 1 considers the area covered by villages that adopted a charter and divides the area according to the type of inheritance system explicitly mentioned in the documents that we were able to encode. At any one point in time three or four different inheritance systems in the region coexisted, since the institutional choice was made in a decentralized fashion at the community level. The erosion of women's rights is 
visible from the shift from egalitarian to soft-patrilineal systems between 1525 and 1630, and from another shift toward a patrilineal system before 1801. A process of gradual convergence to a unique system can be observed, and in particular a clear later dominance of the patrilineal system, which acted as an attractor. Initially, in 1348 , the patrilineal system covered $24 \%$ of encoded charters with a known system, by 1801 it had risen to $97 \%$. Thus, the evolution of inheritance rules is essentially unidirectional, going from equal membership rights for men and women toward an increasing gender discrimination. ${ }^{7}$

Table 1. Inheritance systems on the Trentino commons (surfaces)

\begin{tabular}{lcccc}
\hline & \multicolumn{3}{c}{ Year } & \\
Type of system & 1348 & 1525 & 1630 & 1801 \\
& Black death & Peasant war & Italian crisis & Napoleon shock \\
\hline Egalitarian inheritance & 43,845 & 43,845 & 0 & 0 \\
Soft-Patrilineal inheritance & 6,420 & 6,420 & 54,305 & 2,449 \\
Patrilineal inheritance & 16,643 & 21,472 & 68,592 & 151,306 \\
Primogeniture inheritance & 2,623 & 2,623 & 2,623 & 2,623 \\
& & & & \\
Area with inheritance rules (A) & 69,531 & 74,360 & 125,520 & 156,378 \\
(A) in \% of area with a charter in 1801 & $13.2 \%$ & $14.1 \%$ & $23.8 \%$ & $29.7 \%$ \\
\hline
\end{tabular}

Source: Elaboration on our charters database and on the 1897 cadastral register.

Notes: The surfaces are in hectares and cover the villages with the type of inheritance system in force during a specific year considering the extension of the villages according to the 1897 cadastral register. In 1801 the total area of villages in Trentino that had adopted a charter that was also accessible amounted to 527,281 hectares.

As illustrative cases, consider the reform of the inheritance system that took place in 1583 in the community of Fiemme, a valley consisting of several villages. The Governor of the community explains to the Prince the motivation by stating:

"Up to now in our Fiemme Community we followed the rule that when outsiders married women who were members of our Community, they inherited membership rights and used the commons and the woods as much as any other member who was born in the Community. Since, lately, many outsiders are marrying women of the Fiemme community with the sole purpose of acquiring membership rights [...] our Community has consensually convened that from now on women members of our Community shall not have nor inherit membership rights should they marry an outsider." 8

Hence, the inheritance system switched from egalitarian to soft-patrilineal.

\footnotetext{
${ }^{7}$ A similar pattern of erosion of women's general property rights on the commons was observed by Alfani (2011) in other parts of Northern Italy.

8 "Essendo che in la Comunità nostra de Fieme fori qua se ha osservato, che maritandose le done vicine della Comunità in forestieri hereditarono la vicinanza et godevano in Comuni et Boschi tanto quanto che un altro vicino nativo della valle. .. Et perchè da uno tempo in qua molti foresteri se maridano in done de Fieme solamente per haver detta Vicinanza [...][la comunità] ha deliberato et determinato de Comun Consenso [...] che da qui in poi per l'avenir tutto le done vicine della valle maritandose in foresteri che non siano vicini della valle non debano haver ne hereditar alcuna vicinanza." (Original Manuscript, AST (Archivio Storico di Trento), lat. sect. capsa XII, n.69 and n.72). This provision was also reported in the 1613 charter of Fiemme, chapter 117 (Sartori-Montecroce, 2002).
} 
The community of Fondo, for its part, switched from a soft-patrilineal to a patrilineal system in 1777 by downgrading women's right to access the commons from a membership right to an appropriation right and by removing any entitlement to inheritance: "For the future we do not want to obey the ancient custom with regard to community members who have no son but only one or more daughters;" according to the new rule, the youngest daughter of an insider could use the commons "only during her lifetime, and when she dies, the right to use the commons shall be extinguished; and her heirs shall be foreigners in the same way as if they had never been community members..."9

After listing all documental instances of inheritance regulations, we traced the evolution of inheritance systems village by village over six centuries. Overall, 80 Trentino villages (out of 290 with accessible charters) mentioned inheritance rules in their charter or other related documents. A chart flow of institutional changes between 1202 and 1801 is in Figure 3, which provides a bird's-eye view of all recorded changes. Figure 3 depicts a story of relentless weakening of women's inheritance rights on the commons. According to our data, in the late medieval period women enjoyed the highest levels of equality in property rights on the common property resources. From that period on, there was a steady process of convergence towards a patrilineal system, without backtracking. At the end of the period, 75 villages had a patrilineal system, 3 a soft-patrilineal system, 2 a primogeniture system and none had an egalitarian system. By the time Napoleon invaded Trentino and forcefully removed the charter regime, the process of erosion of women's rights on the commons was already complete.

We identified only one exception to the general tendency to restrict the inheritance of membership rights for women, and that is in one of the villages of the supra-community of Comun Comunale. In 1544 Comun Comunale adopted a patrilineal system and kept it that way until the end of the charter regime. In 1786 the small village of Piazzo adopted its own integrative charter, in addition to the "supra-charter" of Comun Comunale, thereby introducing a soft-patrilineal system. Most likely, Piazzo did not intend to apply this system on the commons of Comun Comunale, but only to Piazzo's commons.

A separate mention is in order for the primogeniture system, which remained an isolated cluster in the flow chart in Figure 3. This system was prevalent in the nearby German speaking villages of SouthTyrol (outside the bishopric of Trentino) and in the two villages of Stramentizzo and Trodena, which were on the linguistic border between the German and Romance speaking territories. These two villages did not modify their inheritance system, and, interestingly, no other Trentino village ever adopted a primogeniture system (Cole and Wolf, 1974).

\footnotetext{
${ }^{9}$ Fondo 1777: “...non vogliamo più per l'avenire osservare l'anticha osservanza con quelli vicini che non hanno eredi maschi ma sollo hano più ò una figliola, ... per quelle che venirà al mondo, e che sarano della vicinanza più non si ha da usare come per il passato ma la figlia più giovine che farà tale eredita del vicinato da suo padre si concede bensì che questa figlia più giovine erediti il vicinato ma solo per la sua vita durante e non d'avantagio valle a dire morto che sarà questa sarà estinto la vicinanza, e li eredi della medema sarano forastieri come se mai fosseron stati vicini, questo servire debba per quelle figlie che venirano al mondo doppo il presente tempo..." (Inama, 1931, p. 24).
} 


\section{Figure 3. Changes in inheritance regulations over six centuries (villages)}

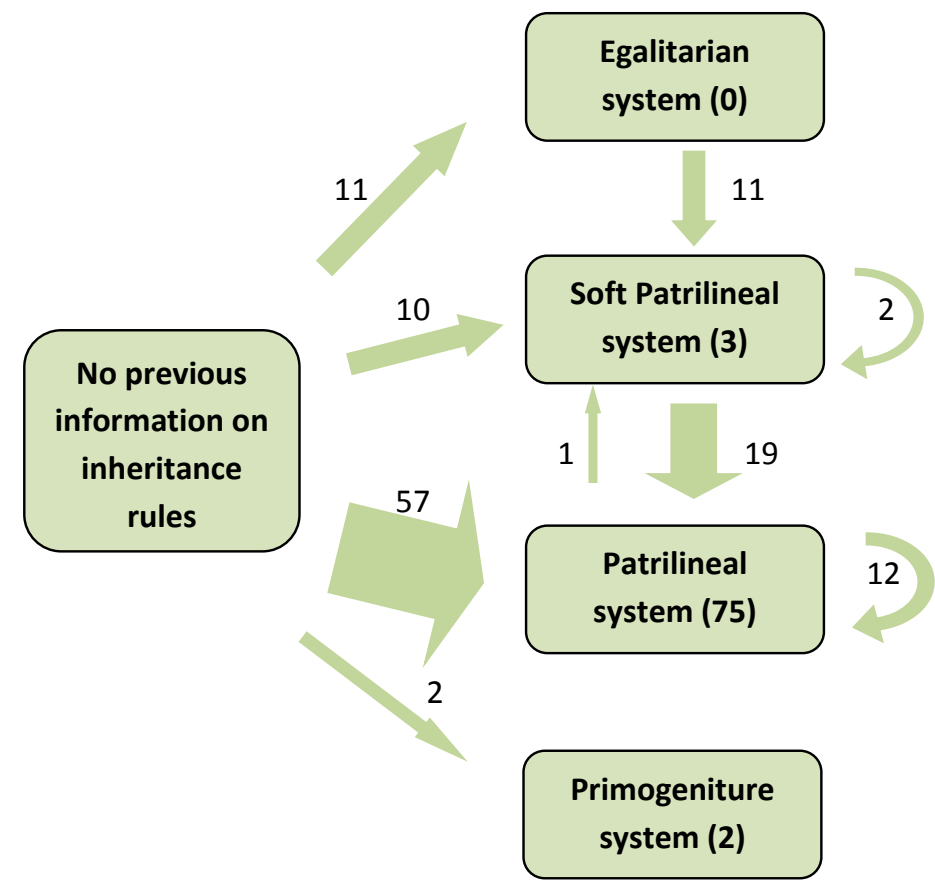

Source: Elaborations on authors' database of charters and other documents.

Notes: Period 1202-1801. One observation consists of one village according to the geographical unit employed in the 1897 cadastral register. Any modification to the type of inheritance system appears in the arrows connecting the four "system" boxes on the right. Curly arrows record restatement and clarifications of membership rights that took place within the same type of inheritance system. One village restricted the soft patrilineal system from all daughters to one daughter only (Cavedine 1764). Some villages belonging to supracommunities restated the rules either of the patrilineal system (Cimone 1768, Isera 1656, Marano 1796, Villa Lagarina 1759) or the softpatrilineal system (Castello di Fiemme 1605) in their village charter. Other communities restated their previous regulations (NagoTorbole 1628, Costa Savina 1739 and 1792, Vigalzano 1739 and 1792, Vervò 1757). Two villages with a patrilineal system specified the rules in more detail (Pieve Tesino 1628, Aldeno 1662). Curly arrows also include modifications to appropriation rights (Mezzolombardo 1777, Aldeno 1753).

The third main finding is that more than $70 \%$ of the villages did not explicitly formalize their inheritance system on the commons. As shown in Table 1, the area without inheritance regulations decreased substantially between 1348 and 1801, but still most charters did not ever mention inheritance rules. What was the system in place in those villages? The evidence about inheritance systems on the commons in the XIII century is scant. However, based on four leads, here we argue that in the late medieval Trentino the egalitarian system on the commons was likely to be widely followed although not formalized. The first lead comes from the 1425 Statute of Trento. Recall that this Statute applied to the whole Bishopric for those aspects that were not regulated in the local charters. The 1425 Statute disciplined the inheritance of private assets but not that of collective properties. It stated that, in the absence of a dowry for the daughters, both sons and daughters inherited the private assets of the parents, although the daughters inherited a lower share. On the subject, the older Statute of 1307 devoted little attention. Secondly, the institutional history of Fiemme, a supra-community that has 
existed as an entity since $1111,{ }^{10}$ reports an explicit description of the egalitarian inheritance system applied to its commons, which was in place until 1583. In that year, as mentioned above, inheritance regulations became soft-patrilineal. Thirdly, the inheritance systems for private and collective properties in the same Fiemme community were identical before $1583 .{ }^{11}$ Fourthly, the oldest documental description of the egalitarian system is not a charter but a 1583 letter of the community governor to the Prince-Bishop. This suggests that many other communities may have followed it as a custom and this was why it was not explicitly written in the charters. Only thirty years later, the 1613 community charter of Fiemme included the transcript of a portion of the letter of the Governor reported above.

To put this documental evidence into a broader context, it should be recalled that charters did not usually regulate all aspects of community life in a systematic way but only encoded problematic aspects, especially those that in the past had generated controversies within the community. The Fiemme Governor's letter is a vivid illustration of a practice of that kind: when the frequency of marriages between local women and foreign men was low, or did not cause conflicts within the community, there was little pressure to encode the inheritance rule into the charters. Another illustration of how charters encoded regulations comes from the explicit norms about the purchase of membership rights by outsiders. One can expect that those communities with immigration pressure were more likely to regulate both membership purchase and membership inheritance. In fact, among the villages that mention membership purchase (79 out of 289), about $68 \%$ also had inheritance regulations at some point. Whereas, among the villages with no mention of membership purchase (210), only $12 \%$ had inheritance regulations. One way to read this regularity is that field controversies were what generated formal regulations.

To draw a conclusion, one can put together the non-systematic codification of inheritance systems on the commons, especially in the early period, as well as the pragmatic spirit of the community charters. If all marriages were between insiders it was practically irrelevant for a community to be under an egalitarian or a patrilineal inheritance system. A marriage between an insider and an outsider had different consequences under the two inheritance systems only if the outsider was the husband and the new family wanted to live in the community of the wife. When no such cases occurred, because there was no immigration pressure toward the community, then the two systems were observationally equivalent. The charter would be changed only when the attempts to immigrate through marriage were frequent or controversial.

\section{Inheritance systems and community size}

We argue that gender discrimination in inheritance regulations emerged as an attempt to limit the size of the community and to protect insiders' wealth. Inheritance regulations in a community could impact its population level through at least two channels, one that altered migration patterns across

\footnotetext{
${ }^{10}$ The Gebardini Pacts, signed on July $14^{\text {th }}, 1111$ between the Bishop of Trento Gebardo and the representatives of the Community of Fiemme, gave judicial and tax autonomy to the Community (see Sartori-Montecroce 2002).

${ }^{11}$ From the 1613 charter, chapter 114 (Le consuetudini di Fiemme - Libro II del civil), in Sartori-Montecroce (ibid.) p. 278.
} 
communities and another that modified incentives for endogenous growth. In the dynamics of community size, migration was a short-run factor while endogenous growth was a long-run factor.

Migrations alone could increase or decrease the size of single communities also in a scenario of stable population at regional level. Assuming that everyone marries, if the spouses are from different communities they can decide to settle down in the community of the husband or in the community of the wife. Assuming further that the family has two children. If private assets are mobile, the family will want to settle in the community that is "richer" in terms of collective resources. Because of this incentive, the young generation of a rich community could attract spouses from poorer communities who want to move in to benefit from access to richer commons. Under an egalitarian inheritance system, if every member of the young generation marries an outsider, the number of families in a community may double. Hence, the per-capita collective wealth in a rich community may halve within the time period of a generation, whereas the poorer communities observe an increase. One has also to consider that cross-community marriages may present some benefits from a collective point of view: small communities - as the ones in Trentino - run into severe risks of consanguinity if all marriages are between insiders, cross-community marriages reduce this risk. Conversely, a patrilineal inheritance system can effectively prevent net immigration via marriage. This system does not forbid marriages with outsiders, but it ensures that the number of families in the next generation will remain the same. In particular, wives will move to their husbands' communities since the new family has no access to the commons of the wife's original community. Hence, under a patrilineal inheritance system on the commons, the community will maintain its size and some genetic mixing will still be possible: for every man marrying an outside woman, one woman of that man's community will have to move out. The same outcome can be achieved through a primogeniture system. ${ }^{12}$

To sum up, if all communities in the region have an egalitarian inheritance system, then the inequality in per-capita collective wealth will decline and reach minimal levels. In contrast to that, if all communities have a patrilineal inheritance system, the inequality in per-capita collective wealth will persist. In case both systems co-exist in the region, what matters is the type of system adopted by the communities better endowed in terms of per-capita collective wealth. In order to avoid reductions in their share of collective resources, insiders of rich communities tend to adopt gender-biased inheritance systems. Contrariwise, the choice about inheritance rules of insiders of poor communities is irrelevant: migratory patterns would be unaffected by their type of inheritance system, whether it is formalized or not. This can explain why we observed many communities without written inheritance regulations (Table 1). A formal model of migratory pressure along these lines is presented in Casari and Lisciandra (2013).

The choice of inheritance system on the commons can make a difference also in terms of fertility rates, and, consequently, on endogenous population growth. This phenomenon has been known at least since Hardin (1968) and it relates to the tragedy of the commons with regard to population control. Parents' decision about the number of kids is private but - when the kids have also access to collective

${ }^{12}$ It is easy to show that the outcome under a soft-patrilineal inheritance system is in-between those of an egalitarian and a patrilineal system. 
resources - it becomes a matter of public concern. When the survival of a family lies exclusively on its own private resources, the family bears the full costs of having an additional child. Instead, if the family relies also on the collective land, the incentives to have children are higher because of the externality of appropriating collective resources. A portion of the cost of the additional child falls on the community at large, whose resources are subject to the typical mechanism of the tragedy of the commons. In an egalitarian inheritance system "everyone born has an equal right to the commons" and this would "lock the world into a tragic course of action" (Hardin, 1968). The solution to the tragedy about population control is a change in the inheritance system. The adoption of a primogeniture system on the commons fully removes the "tragedy" because additional children after the first one do not impose negative externalities on the community commons. A patrilineal system provides a partial solution because it lessens individual incentives to have additional children with respect to the egalitarian system as, in the long-run, only about half of the children, the boys, can count on the community commons. The patrilineal system attenuates, but does not solve, the tragedy about population control because for every additional child there is still some probability that the cost will be shifted to the community at large.

As previously argued, inheritance regulations had an impact on the dynamics of community size. In comparison with a patrilineal system, an egalitarian system increased incentives for both fertility and immigration. On the one hand, in Trentino the incentive for fertility was exacerbated by the presence of low-populated communities with large shares of commons. On the other hand, the existence of large inequalities among villages in per-capita collective wealth and the increment of population in the region triggered internal migrations. Although both fertility and migration push communities toward a change in the inheritance rules in order to protect their collective resource from depletion, we claim that the main drive for the institutional change in inheritance rules was the attempt to reduce migratory pressure occurring through marriage, because migration operates more quickly and is more "visible" than endogenous population growth. Hence, the remaining of the section discusses migrations.

Migration mainly occurs because individuals from poor communities may want to move into a rich community. Therefore, a high inequality in per-capita collective wealth across communities gives rise to this course. Unfortunately, we lack systematic data about migratory flows, size, and wealth at the community level over the six centuries, but we have been able to construct an inequality index for thirty-two villages using 1780 cadastral data and 1810 population census data. ${ }^{13}$ The resulting Gini index in per-capita collective wealth shows a high level of inequality (0.61). The corresponding index in per-capita total wealth denotes a lower level of inequality (0.27). The difference in the two indices denotes how commons were more unequally distributed than individual properties. This suggests that communities with a higher commons endowment may have acted to prevent the leveling-off in commons wealth among the communities in the region.

The reason for the persisting inequality across villages in the value of per-capita collective wealth, we believe, was the occurrence of a series of shocks on population and wealth in the form of fires, landslides, flooding, famines, and plagues. These factors caused divergence because the shocks were

${ }^{13}$ This sample from the 1780 register corresponds to 37 villages in the 1897 cadastral register (10\% of all villages). 
likely to hit villages in an asymmetric fashion. Since shocks could occur, perfect equality was unlikely even in a society that universally adopted an egalitarian system. The frequency and magnitude of the asymmetric shocks were likely to dominate the speed of population adjustments, the latter being less intense with patrilineal inheritance systems. ${ }^{14}$

\section{Figure 4. Population estimates in the Centre-North of Italy and Trentino}

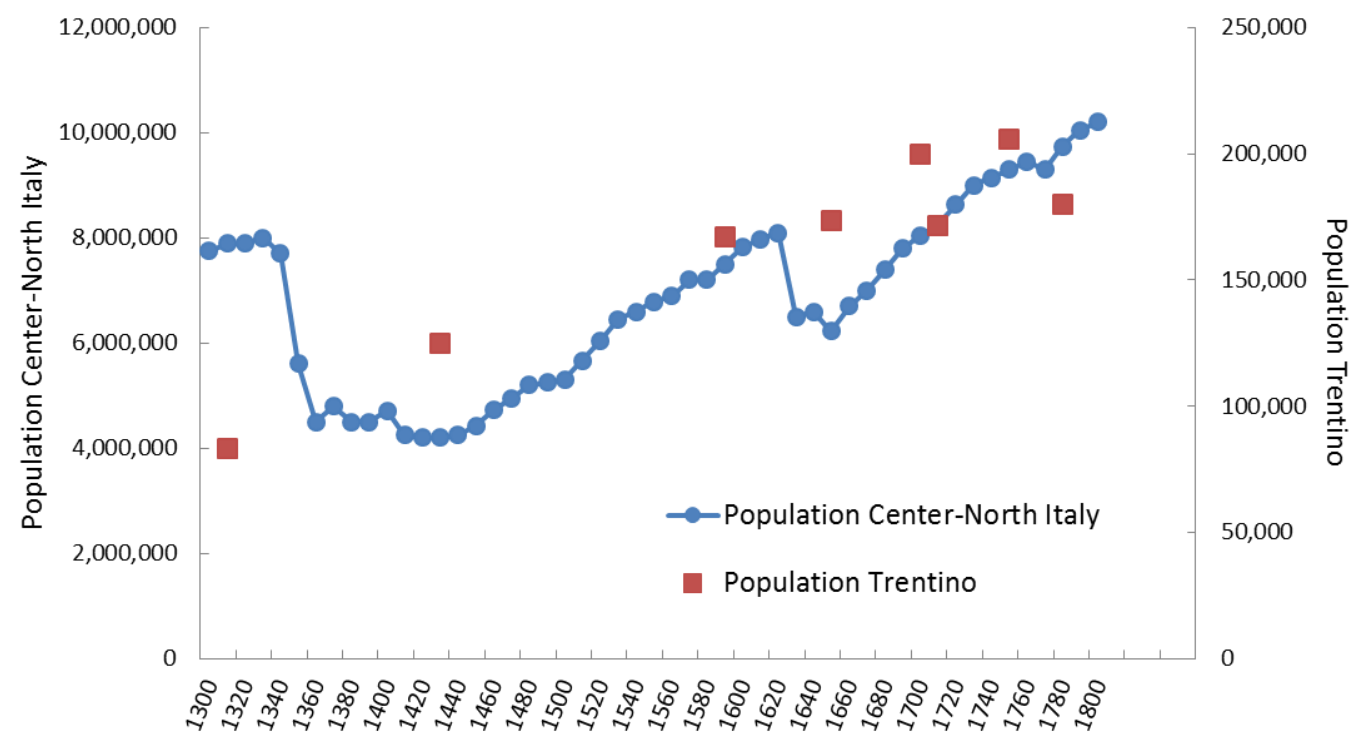

Source: Malanima (2002) for the Centre-North of Italy. Cole and Wolf (1974) for Trentino in years 1312, 1427, 1650, 1754. Further Trentino estimates: Debiasi (1953) in 1700; Franceschini (2009) in 1594, 1704; Chiocchetti and Chiusole (1965) in 1780.

Notes: The Centre-North of Italy includes Piedmont, Val d'Aosta, Nice, Monaco, Lombardy, Veneto, Trentino-Alto Adige, Friuli, Istria, Liguria, Emilia-Romagna, Tuscany, Umbria, and Marche. Fiebiger (1959) estimates that Trentino made up 34.7\% of the entire Tyrol population in 1754. We applied this fraction to the estimates of Tyrol population in Wopfner (1954) for antecedent dates. The Trentino population estimates in Franceschini (ibid.) refer to the 1573-1615 and 1685-1723 time intervals, for which we considered the median years 1594 and 1704, respectively.

Migratory pressure will be even stronger when regional population increases. The available evidence refers to population estimates for the Centre-North of Italy and for Trentino (Figure 4). Overall, the population in Centre-North Italy grew from 1300 to 1800 by 32\%, whereas in Trentino from 1312 to 1754-1780 by $131 \%$. More precisely, population estimates for Trentino come from a variety of sources and are of 83,373 units in 1312 and 167,000 units in 1594, 206,000 in 1754, and 180,000 in $1780 .{ }^{15}$ Although we have only scattered estimates of Trentino population, the patterns for Centre-North Italy

\footnotetext{
${ }^{14}$ After centuries under an egalitarian inheritance system, one may expect that both migrations and endogenous population growth should have brought about a situation of near equality. Direct support for this view requires evidence that we cannot provide on the inequality levels at the time when communities started to restrict women's inheritance rights. However, as documented in the previous section, restrictions occurred over time without a clear-cut switch. Furthermore, if migrations and endogenous population growth had indeed generated equality in per-capita collective wealth by, say, the end of XVI century, one needs to explain what produced the inequality observed two centuries later. Consider that long-run convergence in per-capita collective wealth should have occurred also after women's inheritance rights started to be restricted, assuming that fertility were positively related to per-capita wealth.

15 According to Malanima (2002) the population in the Centre-North Italy in 1620 was $8,100,000$, whereas in 1800 was 10,120,000. The $131 \%$ increase in Trentino population considers the average between the estimates of 1754 and 1780 .
} 
and Trentino appear similar. In particular, from the more systematic data of the entire Centre-North of Italy, one can identify some focal dates that marked a change in the direction of population growth and levels, such as the Black Death of 1348 and the Italian crisis of 1630.

These population patterns can explain the institutional change that are observed in inheritance regulations. The frequency of inheritance regulations on the commons in community documents increases in periods of population growth. More specifically, Table 2 illustrates the number of first mentions or changes in inheritance regulations broken down by periods of regional population increase and decrease. This evidence appears to point to the role of demographic pressure in the institutional change. A more systematic analysis will be provided in the following section.

Table 2. Population trends and inheritance regulations (documents)

\begin{tabular}{clccc}
\hline $\begin{array}{c}\text { Time } \\
\text { Interval }\end{array}$ & \multicolumn{1}{c}{ Population trend } & $\begin{array}{c}\text { Number of documents } \\
\text { reporting inheritance } \\
\text { regulations (A) }\end{array}$ & $\begin{array}{c}\text { Number of encoded } \\
\text { charters (B) }\end{array}$ & (A)/(B) \\
\hline $1200-1347$ & Increase & 2 & 14 & $14.3 \%$ \\
$1348-1430$ & Decrease & 1 & 22 & $4.5 \%$ \\
$1431-1600$ & Increase & 16 & 135 & $11.9 \%$ \\
$1601-1630$ & Increase (above 1348 level) & 8 & 21 & $38.1 \%$ \\
$1631-1650$ & Decrease & 6 & 12 & $25.0 \%$ \\
$1651-1700$ & Increase & 24 & 18 & $33.3 \%$ \\
$1701-1800$ & Increase (above 1630 level) & 68 & $30.8 \%$ \\
\hline
\end{tabular}

Source: Elaboration on authors' database of charters and related archival documents. Population trends are from Malanima (2002) and refer to Centre-North Italy.

Notes: (A) includes all documents mentioning both first formalization and subsequent restrictions or restatements of inheritance regulations. The number of documents (A) and the number of encoded charters (B) here reported exclude those documents mentioning the inheritance systems but having an antecedent charter - in previous time intervals - existing but unavailable. These documents refer to the following communities: Croviana, Giovo and Faedo, Matarello, Varignano, Vervò, Vezzano and Padergnone. For example, Croviana mentions the inheritance system in the 1727 charter, however the previous charter was written in 1427 but it is unavailable. This is to avoid that we count charters mentioning the inheritance system that could have previous charters also mentioning the inheritance system and that actually introduced the inheritance regulation. Further, the number of encoded charters includes both first and subsequent charters.

In sum, we observe two factors triggering internal migrations: inequalities in the values of per-capita collective wealth and regional population growth. Both factors induced communities to adjust their inheritance systems on the commons in order to restrict the influx of outsiders and to protect collective resources. In particular, wealth inequalities help to explain why some communities adopted inheritance regulations whereas others did not, while the regional population growth had more to do with the timing of institutional change.

\section{Empirical evidence}

This section presents a regression analysis about the factors influencing the introduction of inheritance regulations in each village. The empirical analysis includes two models of inheritance regulations adoption, one static and one dynamic. The static model presents factors that influenced the decision of a community to introduce inheritance regulations at any point in time before 1800 (inheritance). The dynamic model is an event history model aiming to explain - during the entire period under scrutiny which factors influenced the occurrence of the first formalization of inheritance systems (event). One 
village is the unit of observation and corresponds to a geographic entity in the 1897 cadastral register. Out of the 366 villages in the cadastral register, the dataset considers the 289 villages that had adopted a charter by the year 1800 . Those villages had at least one encoded charter in our database. ${ }^{16}$

\section{Static model}

The static model explains the village adoption of an inheritance regulation at any one time before 1800 (Tables 3 and 4). Proxies are built for the size of the village, its remoteness and wealth. The proxy for village size is the village population taken from the 1810 census (pop1810). ${ }^{17}$ Proxies for village remoteness are the walking distance in $\mathrm{km}$ (dis_tn) and the altitude difference (diffalt_tn) from Trento, the regional capital, which has a central position in the region (Figure 2). The two proxies are weakly correlated $(\rho=0.38)$.

Proxies for wealth include the per-capita value of collective land ( $\left.p c \_c o m m o n \_v a l u e\right)$ and the percapita value of total village land ( $\left.p c \_t o t a l \_v a l u e\right)$. These variables use the 1897 cadastral register data on surfaces and the 1810 census data about village population (pop1810). We based the estimates of land value per hectare and ownership shares on the 1780 cadastral register. The value of collective land in a village (common_value) results from considering three factors: the surface of the 1897 land by type multiplied by the 1780 estimated land values by type, and then multiplied by the 1780 estimated ownership share of collective land. The resulting value was divided by the 1810 village population to obtain the variable $p c \_c o m m o n \_v a l u e$.

The 1897 data cover all villages in the region while we have the 1780 data only for about $10 \%$ of villages. Our data on the 1897 register includes the surface for each type of land by village but neither rent nor ownership records. Because the land classifications in the 1780 and 1897 registers were slightly different (e.g., what is called grazing land in one dataset may be classified as meadows in the other), we carried out an analysis on surfaces to identify the best way to match the two sources. We then used the 1780 land rents to compute the relative value of each type of land. Forests, grazing land, and alps pooled together served as numeraire. Vineyards, for instance, were worth per hectare about 5.5 times the numeraire. Finally, we employed the 1780 ownership shares for each type of land to estimate collective land on the 1897 surface data. ${ }^{18}$ The value of total land in a village (total_value) is the sum of the values of collective and individual land. The estimate of land value by type could differ between individual and collective land. For each type of land we estimated land values separately by ownership according to the 1780 rents.

\footnotetext{
${ }^{16}$ Trento, the capital town, was dropped from the original 290 villagesdataset; those villages were characterized by at least one encoded charter.

${ }^{17}$ Andreatta and Pace (1981). As in Casari (2007), when break-downs at the village level is not available, we use as shares the proportions from 1897 data (Consiglio provinciale d'agricoltura pel Tirolo, 1903).

${ }^{18}$ pc_common_value $=$ Total value of collective land $/$ village population. Total value of collective land $=\Sigma_{\text {by land type }}(1780$ value of land type $) \times(1780$ ownership share of land type $) \times(1897$ surface of land type $)=7.72 \times 0.255 \times($ meadows $)+$ $0.725 \times$ (grazing land+alps+forest) $+8.93 \times 0.137 \times$ (plow land $)+22.92 \times 0.015 \times($ fruit and garden $)+5.56 \times 0.003 \times($ vineyard $)$. Total value of private land $=10.19 \times(1-0.255) \mathrm{x}($ meadows $)+0.91 \times(1-0.725) \times($ grazing land + alps + forest $)+10.51 \times(1-$ $0.137) \times($ plow land $)+24.59 x(1-0.015) \times($ fruit and garden $)+13.12 x(1-0.003) \times($ vineyard $)$.
} 
An additional wealth variable provides the value of collective land divided by the value of individual land (ratio_value). In the empirical model, this ratio can capture the presence of production complementarities between collective and individual land. Consider that collective land consisted generally of mostly forest, alps, and pastures at high altitudes while private land was mostly made up of cropland and meadows at low altitudes. Cattle grazing, for instance, is more productive if meadows at low altitude are used during wintertime and grazing land and alps at high altitude are used during summertime. Each village needed both types of land for efficient agricultural production. Across villages there is a high correlation between the surfaces of collective land and individual land $(\rho=0.97)$. A similar correlation is reported for land value $(\rho=0.78)$. Table 3 below summarizes the statistics of all the variables mentioned above.

Table 3. Summary statistics

\begin{tabular}{lcccc}
\hline & Mean & Std. Dev. & Min & Max \\
\hline $\begin{array}{l}\text { Dependent variables } \\
\text { inheritance }\end{array}$ & .277 & .448 & 0 & 1 \\
inheritance or membership purchase & .398 & .490 & 0 & 1 \\
& & & & \\
Independent variables & & & & \\
pop1810 & 633.26 & 719.38 & 52 & 7069 \\
dis_tn & 48.67 & 28.92 & 2.90 & 129 \\
diffalt_tn & 483.41 & 289.39 & -121 & 1385 \\
pc_common_value & 2.47 & 1.96 & .08 & 19.45 \\
pc_total_value & 7.42 & 3.56 & .80 & 31.11 \\
ratio_value & .48 & .27 & .092 & 1.67 \\
\hline
\end{tabular}

Source: Dataset constructed by the authors.

Notes: The number of observations is 289 . Trento has not been included because it is the capital town. "Inheritance or membership purchase" is a dependent variable coded as 1 if a village either had inheritance regulation or gave outsiders the possibility to purchase membership or both, and as 0 if otherwise.

Among the regressors there are proxies for community remoteness (dis_tn and diffalt_tn) and wealth ( $p c \_c o m m o n \_v a l u e, p c \_t o t a l \_v a l u e$, and ratio_value). Since villages that adopted formal inheritance regulations could have different population dynamics to villages that did not adopt any regulation, it is likely that there are issues of endogeneity of the community size variable (pop1810). As a consequence, the variables $p c \_c o m m o n \_v a l u e$ and $p c \_t o t a l \_v a l u e$ could suffer from the same problem. For this reason the model estimation employs an instrumental variable probit. Given the small set of variables available, we use as instruments common_value and total_value respectively for their corresponding per-capita variables. ${ }^{19}$

The static model shows four specifications (Table 4). In all specifications a Wald test of exogeneity confirms the presence of endogeneity in the structural equation and, consequently, the correctness of

\footnotetext{
19 The instruments satisfy the correct requirements. The correlations between $p c_{-}$common_value and its instrument is 0.50 , and between $p c \_t o t a l$ value and its instrument is 0.26 . The correlations do not appear strong, especially the second. However, we performed weakness tests on the instruments by considering the robustness of the F-statistics in the first-stage of the 2 sls linear probability models. The instruments appear robust: common_value at $1 \%$ and total_value at $5 \%$.
} 
the adoption of the instrumental variable technique. ${ }^{20}$ Specification (1) uses as regressors the two proxies of remoteness and the per-capita proxy for common land. The per-capita value of collective land significantly and positively influence the introduction of formal inheritance rules. This supports the interpretation that communities more endowed in per-capita collective wealth are induced to formalize inheritance regulations in order to protect their wealth. In addition, more remote villages in terms of altitude were significantly less likely to formalize inheritance rules (diffalt_tn). Our interpretation is that villages in the high mountains did not need to formalize inheritance systems because they were far from any migration routes threatening their commons. Walking distance (dis_tn) from Trento is weakly significant with a negative coefficient. One may expect a weak significance of its coefficient because high walking distance also includes easily accessible villages.

Table 4. Regulations about inheritance on the commons by 1800 (static model)

\begin{tabular}{|c|c|c|c|c|}
\hline $\begin{array}{l}\text { Dependent variable } \\
(1=\text { regulation, } 0=\text { otherwise })\end{array}$ & $\begin{array}{c}\text { Inheritance } \\
\text { regulation } \\
\\
(1) \\
\end{array}$ & $\begin{array}{c}\text { Inheritance } \\
\text { regulation } \\
\\
(2) \\
\end{array}$ & $\begin{array}{l}\text { Inheritance or } \\
\text { membership } \\
\text { purchase } \\
\text { regulation } \\
(3)\end{array}$ & $\begin{array}{c}\text { Inheritance or } \\
\text { membership } \\
\text { purchase } \\
\text { regulation } \\
(4)\end{array}$ \\
\hline dis_tn & $\begin{array}{c}-0.0112 \\
(0.0067)^{*}\end{array}$ & $\begin{array}{l}-0.0091 \\
(0.0063)\end{array}$ & $\begin{array}{c}-0.0162 \\
(0.0067) * *\end{array}$ & $\begin{array}{c}-0.0116 \\
(0.0063)^{*}\end{array}$ \\
\hline diffalt_tn & $\begin{array}{c}-0.0020 \\
(0.0005)^{* * *}\end{array}$ & $\begin{array}{c}-0.0011 \\
(0.0005)^{* *}\end{array}$ & $\begin{array}{c}-0.0020 \\
(0.0004)^{* * *}\end{array}$ & $\begin{array}{c}-0.0010 \\
(0.0004)^{* *}\end{array}$ \\
\hline pc_common_value & $\begin{array}{c}0.2564 \\
(0.1230)^{* *}\end{array}$ & & $\begin{array}{c}0.2597 \\
(0.1211)^{* *}\end{array}$ & \\
\hline pc_total_value & & $\begin{array}{c}0.3324 \\
(0.0455)^{* * *}\end{array}$ & & $\begin{array}{c}0.3475 \\
(0.0360)^{* * *}\end{array}$ \\
\hline ratio_value & & $\begin{array}{c}-2.5567 \\
(0.5812)^{* * *}\end{array}$ & & $\begin{array}{c}-2.7303 \\
(0.5527)^{* * *}\end{array}$ \\
\hline Constant & $\begin{array}{l}-0.3107 \\
(0.3103)\end{array}$ & $\begin{array}{c}-1.3245 \\
(0.3453)^{* * *}\end{array}$ & $\begin{array}{c}0.5627 \\
(0.3069)^{*}\end{array}$ & $\begin{array}{c}-0.8710 \\
(0.3764)^{* *}\end{array}$ \\
\hline Wald test of exogeneity (Prob $\left.>\chi^{2}\right)$ & 0.0125 & 0.0022 & 0.0044 & 0.0002 \\
\hline log likelihood & -637.8 & -821.4 & -666.7 & -847.9 \\
\hline Number of observations & 289 & 289 & 289 & 289 \\
\hline
\end{tabular}

Source: Database constructed by the authors.

Notes: Instrumental variable probits. Dependent variables: inheritance regulation, inheritance or membership purchase regulation. To control for fixed effects, 12 area dummies are included among regressors; they are not reported in the table. Trento, the capital town, has not been included. The figures in parenthesis are standard deviations. * denotes significance at a 10 percent level, ** at a 5 percent level, and $* * *$ at a 1 percent level.

In specification (2) there are two alternative wealth proxies: the per-capita value of total village land ( $\left.p c \_t o t a l \_v a l u e\right)-$ which is interesting because it removes issues about incorrect estimates of ownership shares - and the value ratio between collective vs. individual land (ratio_value), which can capture complementarities in production between different types of land independently of village size. This latter regressor is not in specification (1) because of multi-collinearity issues. The higher the percapita value of total land the more likely it was that the village had inheritance regulations. Moreover, a lower ratio is associated with a higher frequency of inheritance regulations. Those villages with

${ }^{20}$ A rejection of the null hypothesis of exogeneity means that the error terms in the structural equation and the reduced-form equation for the endogenous variable are correlated. Thus, instrumenting the endogenous variable was correct. 
relatively scarce commons with respect to their individual land may have suffered more from an influx of outsiders because of existing complementarities between collective and individual land. Conversely, villages relatively more endowed with collective than individual land, did not feel threatened by newcomers and the increase in their population.

As a robustness check, specifications (3) and (4) replicate the static model using an alternative dependent variable. Because of archival issues or destroyed documents, it is possible that we missed documents that regulated inheritance. For this reason we also considered the villages that regulated membership purchase. The introduction of a regulation on the purchase of membership rights points toward a pressure coming from people who wanted to move into the community. Regulation on membership purchase could be seen as another instrument to regulate migratory pressures. Depending on the village, the quorum required for accepting outsiders through membership purchase was between a simple majority and unanimity of insiders. This alternative variable takes value 1 if the village either regulated inheritance or gave outsiders the possibility to purchase membership or both, and 0 if otherwise. Both the inheritance and membership regulations were proxies of the village closure against migratory pressures. Specifications (3) and (4) confirm all results emerging from specifications (1) and (2).

\section{Dynamic model}

A dynamic model can exploit both whether and when a village formalized inheritance regulations. The timing of inheritance regulations varied considerably across villages (Figure 2). An event history model is used to obtain the estimates presented in Table 5. This estimation technique relies on an event or transition, which in our case is the time of adoption of written inheritance regulations on the commons in a given village. The dataset is a panel based on the 289 villages as in the static model with observations at five-year time intervals between the years 1200 and 1800. As long as there is no transition the dependent variable is set to zero, if the event occurs the dependent variable is set to 1 and the village is then deleted from the subsequent time intervals of the data set. The event history model estimates the probability that the event occurs in the time interval between $t$ and $t+5$, conditional on the village not having experienced the event at or before time $t$ (risk set). The equation employed to estimate the event history model is the following probit equation:

$$
\Phi^{-1}[\mathrm{P}(\mathrm{t})]=\mathrm{a}(\mathrm{t})+\mathrm{b}_{1} \mathrm{X}_{1}+\mathrm{b}_{2} \mathrm{X}_{2}(\mathrm{t})+\mathrm{u}(\mathrm{t})
$$

wherein $\Phi$ is the standard normal cumulative distribution function, $P(t)$ is the hazard rate consisting of the ratio between the number of events occurred in time $t$ (i.e., formalization of inheritance regulation on the commons) and the number of "surviving" villages in time $t$ (risk set) ${ }^{21} a(t)$ is the time trend; $X_{1}$ is the vector of time-invariant variables; $X_{2}$ is the vector of time-variant variables; $u(t)$ is the i.i.d. error term such that $\mathrm{E}[u(t)]=0$ and $\operatorname{Var}[u(t)]=\sigma^{2}$.

${ }^{21}$ Put differently, $P(t)$ is the probability that a village adopts a regulation of the inheritance system on the commons at time $t$. 
Table 5. Regulations about inheritance on the commons (dynamic model)

\begin{tabular}{|c|c|c|c|c|}
\hline $\begin{array}{l}\text { Dependent variable: } \\
\text { event }=1 \text { if adopted regulation in the } \\
\text { time period, }=0 \text { if not yet adopted }\end{array}$ & $\begin{array}{c}\text { Inheritance } \\
\text { regulation } \\
(1) \\
\end{array}$ & $\begin{array}{c}\text { Inheritance } \\
\text { regulation } \\
(2) \\
\end{array}$ & $\begin{array}{c}\text { Inheritance or } \\
\text { membership } \\
\text { purchase regulation } \\
\text { (3) }\end{array}$ & $\begin{array}{c}\text { Inheritance or } \\
\text { membership } \\
\text { purchase regulation } \\
\text { (4) }\end{array}$ \\
\hline poptime_cn & $\begin{array}{c}0.0001 \\
(0.0001)^{* *}\end{array}$ & $\begin{array}{c}0.0002 \\
(0.0001)^{* *}\end{array}$ & $\begin{array}{c}0.0001 \\
(0.0001)^{* *}\end{array}$ & $\begin{array}{c}0.0002 \\
(0.0001)^{* * * *}\end{array}$ \\
\hline Poptrend & $\begin{array}{c}0.2818 \\
(0.1309)^{* *}\end{array}$ & $\begin{array}{c}0.2770 \\
(0.1309)^{* *}\end{array}$ & $\begin{array}{c}0.3155 \\
(0.1157) * * *\end{array}$ & $\begin{array}{c}0.3115 \\
(0.1158)^{* * *}\end{array}$ \\
\hline dis_tn & $\begin{array}{c}-0.0025 \\
(0.0030)\end{array}$ & $\begin{array}{c}-0.0013 \\
(0.0031)\end{array}$ & $\begin{array}{c}-0.0041 \\
(0.0029)\end{array}$ & $\begin{array}{l}-0.0031 \\
(0.0030)\end{array}$ \\
\hline diffalt_tn & $\begin{array}{c}-0.0006 \\
(0.0002)^{* *}\end{array}$ & $\begin{array}{c}-0.0006 \\
(0.0002)^{* *}\end{array}$ & $\begin{array}{c}-0.0006 \\
(0.0002) * * *\end{array}$ & $\begin{array}{c}-0.0006 \\
(0.0002) * * *\end{array}$ \\
\hline pc_common_value & $\begin{array}{c}-0.0024 \\
(0.0270)\end{array}$ & & $\begin{array}{c}-0.0113 \\
(0.0245)\end{array}$ & \\
\hline pc_total_value & & $\begin{array}{c}0.0205 \\
(0.0151)\end{array}$ & & $\begin{array}{c}0.0182 \\
(0.0129)\end{array}$ \\
\hline ratio_value & & $\begin{array}{c}-0.3569 \\
(0.2430)\end{array}$ & & $\begin{array}{c}-0.3903 \\
(0.2111)^{*}\end{array}$ \\
\hline f_centerin & $\begin{array}{c}0.8518 \\
(0.2395) * * *\end{array}$ & $\begin{array}{c}0.8613 \\
(0.2406)^{* * *}\end{array}$ & $\begin{array}{c}0.8664 \\
(0.1820) * * *\end{array}$ & $\begin{array}{c}0.8814 \\
(0.1828) * * *\end{array}$ \\
\hline Constant & $\begin{array}{c}-3.0122 \\
(0.1881)^{* * *}\end{array}$ & $\begin{array}{c}-3.0769 \\
(0.2048)^{* * *}\end{array}$ & $\begin{array}{c}-2.7730 \\
(0.1595) * * *\end{array}$ & $\begin{array}{c}-2.8158 \\
(0.1724) * * *\end{array}$ \\
\hline $\begin{array}{l}\text { Pseudo-R2 } \\
\text { log likelihood }\end{array}$ & $\begin{array}{r}0.086 \\
-5103\end{array}$ & $\begin{array}{r}0.089 \\
-5089\end{array}$ & $\begin{array}{r}0.066 \\
-7050\end{array}$ & $\begin{array}{r}0.069 \\
-7031\end{array}$ \\
\hline Number of observations & 31,618 & 31,618 & 30,122 & 30,122 \\
\hline
\end{tabular}

Source: Database constructed by the authors.

Notes: Event history model (probit function). To control for fixed effects, 12 area dummies are included among regressors; they are not reported in the table. All villages are in the dataset at the starting date. Trento, the capital town, has not been included. The figures in parenthesis are standard deviations. * denotes significance at a 10 percent level, ** at a 5 percent level, and *** at a 1 percent level.

In the dynamic model the time-invariant regressors are the walking distance from Trento (dis_tn), the difference in altitude with Trento (diffalt_tn), and the ratio between the value of collective and individual land (ratio_value) as in the static model. There are five time-variant regressors. A village size estimate at time $t$ (poptime_cn), which is built by taking the 1810 village population and scaling it using the ratio between the Centre-North Italy population at time $t$ and in the year $1800{ }^{22}$ The percapita value of total village land (pc_total_value) and the per-capita value of the commons ( $p c_{-}$common_value) are built by taking the corresponding static model variables and dividing them by poptime_cn. The direction of population change in the Centre-North of Italy (poptrend) is a binary variable that takes value 0 when regional population decreased and 1 when it increased over the time intervals presented in Table 2. Finally, the model includes a variable about contagion $\left(f_{-}\right.$centerin), which consists of the fraction of villages around the same reference center that have already adopted inheritance regulations at time $t .^{23}$ Notice that the population variable and the per-capita variables are

\footnotetext{
${ }^{22}$ For the population of Centre-North Italy see Malanima (2002). However, the data in Malanima do not cover the XIII century. The population data available for Italy in Bellettini (1987) have been used to rescale villages population in 1300 backward to 1200 .

${ }^{23}$ The 17 reference centers are: Borgo, Canale S. Bovo, Canazei, Cavalese, Cles, Condino, Fondo, Levico, Malè, Mezzolombardo, Pergine, Pinè, Riva del Garda, Rovereto, Stenico, Tione, Trento.
} 
no longer endogenous as in the static model and are now included. This is the peculiarity of the history event model since, once the event (i.e., adoption of regulation) has occurred, the village is dropped from the dataset for the remaining time intervals.

The results from the dynamic model presented in Table 5 are in line with those of the static model. In specifications (1) and (2) the dependent variable is the adoption of inheritance regulations in a given 5year time interval. Remoteness and wealth proxies have the correct sign. While remoteness in terms of altitude is significant, wealth proxies are non-significant. We have reasons to believe that the lack of significance of the wealth proxies could originate from their inaccuracies. We have neither cadastral data nor regular population census for each time interval along the six centuries considered. During such long horizon villages could have sold, purchased, individualized collective properties, or changed community boundaries through mergers and fissions.

Following specifications (1) and (2), there are three interesting findings coming from the time-variant regressors. First, in periods of regional population growth (poptrend), villages were significantly more likely to adopt inheritance regulations, which is consistent with our view of regional population growth as a trigger for institutional change. Second, inheritance regulations spread by contagion. The more widespread the adoption of inheritance regulations in nearby villages had been, the significantly more likely was the village itself to adopt a regulation $\left(f_{-}\right.$centerin). An interpretation is that inheritance systems in nearby villages shifted the migratory pressure onto other close villages without clear inheritance restrictions. Those villages could then decide to formalize inheritance rules as a defensive measure, which they may have not done otherwise. Third, larger villages in terms of population were significantly more likely to adopt inheritance regulations (poptime_cn). This finding builds on Casari (2007), which shows that the largest villages were more likely to adopt a charter, and also to have more ancient charters. The existing correlation between group size and inheritance regulations is not the consequence of a selection bias because villages that did not adopt a charter were excluded from the regressions.

Also for the dynamic model we performed the robustness check using an alternative dependent variable. Specifications (3) and (4) in Table 5 explain the adoption of inheritance or membership purchase regulations or both. These confirm all results emerging from specifications (1) and (2). In addition, they largely strengthen the statistical significance of the above results. Importantly, the value ratio of collective vs. individual land is here weakly significant and with the same sign as in the static model.

\section{Discussion}

This section touches upon three issues related to inheritance regulations: (i) the implications for genetic health, (ii) the viability of a matrilineal system as an alternative way to close the community, and (iii) the consequences of the exogenous removal of the charters regime by Napoleon at the beginning of the XIX century. These issues will be developed in the same order. 


\section{Figure 5. Closure of communities: two centuries of endogamy in marriage}

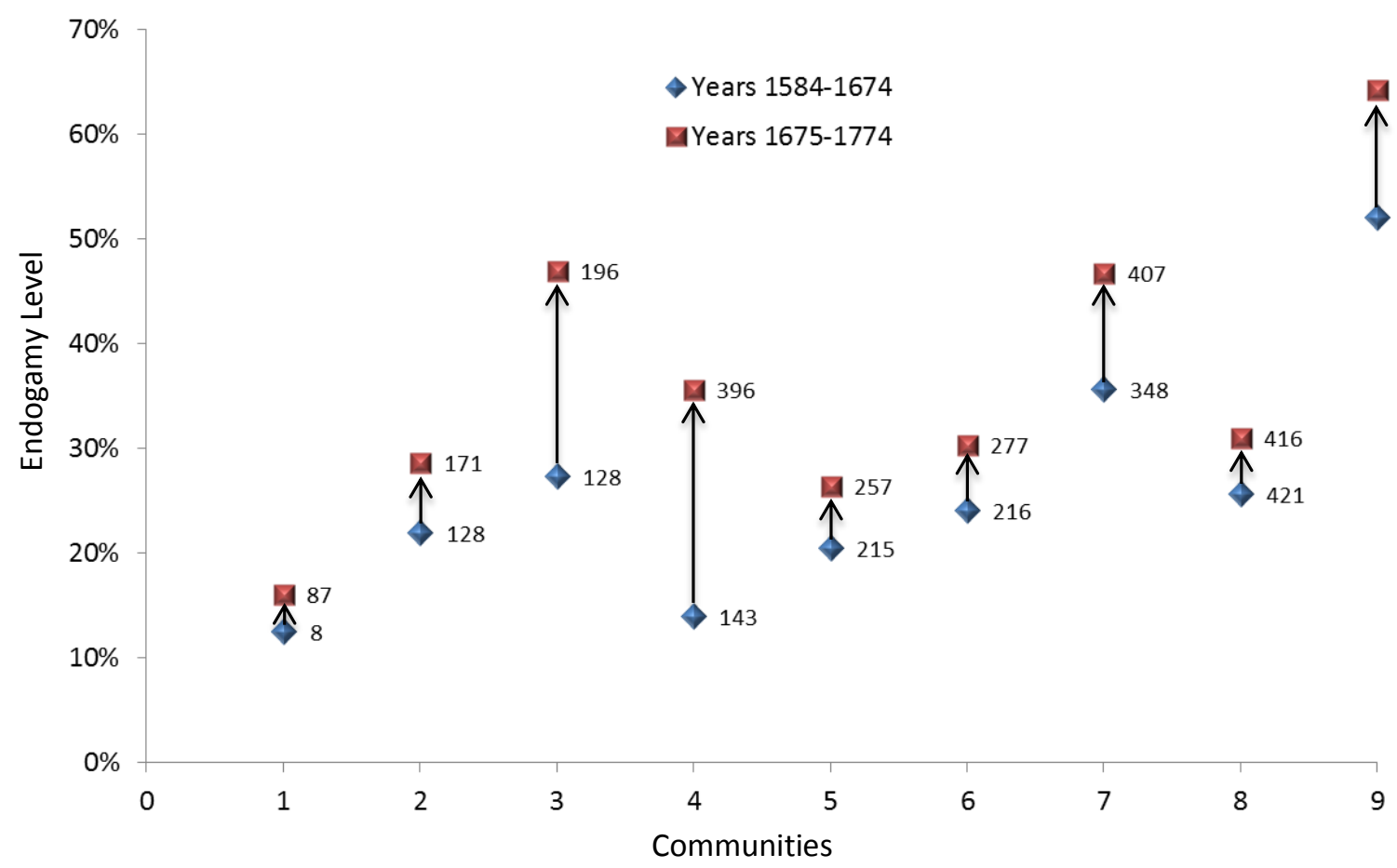

Source: Motta (1978) from parish registers.

Notes: 8 parishes nearby the Fersina Valley ordered from the smallest to the largest, plus the entire valley (Obs. 9); the number of total marriages in the period is noted next to each marker. Endogamy is measured as the frequency of marriages among spouses that were living in the same parish. The total sum of marriages across the 8 parishes is higher than the number of marriages in the Fersina Valley; the reason may lie in classifying part of the parishes as being outside the Fersina Valley.

(i) The wave of adoptions of inheritance systems that restricted women's rights generated a progressive social closure of the communities, which reflected also on marriage patterns and, consequently, on societal genetic health. In the early modern period, one can see a general trend of increasing endogamy in marriage within the Trentino communities. This statement is based on data from marriage registers of 17 parishes across a time span that varied among parishes and covers selected years between 1584 and 1800. One measure of endogamy level is the frequency of matrimonial dispensations for consanguinity and another measure is the frequency of marriages between spouses living in the same parish. The Fassa Valley showed an increasing trend in both measures of endogamy levels during the entire $18^{\text {th }}$ century. The two measures were positively correlated when considering 10 -year intervals $(\rho=0.41, \mathrm{~N}=10)$. This evidence supports the use of the frequency of marriages between spouses coming from the same parish as another measure of endogamy. Even more interesting is the case of the parishes in the Fersina Valley, for which we compared the average endogamy levels in years 15841674 vs. years 1675-1774 (Figure 5). When controlling for parish size, we estimated a 7 percentagepoint increase in the average level of endogamy before and after $1675 .^{24}$ This evidence points toward a

${ }^{24}$ For statistical reasons, in a large parish in terms of number of marriages there was a higher frequency of spouses who
were both living in the same parish, which is our available measure of endogamy level in the Fersina valley. A tobit
regression on the endogamy level $[0,1]$ uses as independent variables the number of marriages in years $1584-1674$ and
$1675-1774$, and a dummy variable for the $1584-1674$ period. Thus, the total number of observations is 18 when considering 
progressive closure of the Trentino communities, which became more inward-looking when choosing marriage partners. ${ }^{25}$

(ii) Unlike gender-biased inheritance systems, egalitarian systems encourage population growth, especially in attractive communities. In Trentino, the institutional change shifted the society toward a patrilineal system for property rights on the common resources. An alternative path could have been a shift toward a matrilineal system, where men lost their rights. According to the interpretation in section 4, a matrilineal system would have accomplished the same results as a patrilineal system.

Patrilineal inheritance systems on collective resources have been the most widespread systems around the world. There exist, however, ethno-linguistic groups with matrilineal inheritance on common property land. We briefly describe three cases: central and southern Malawi, Sumatra, and the Garos ethnic group in North-Eastern India. In the modern Malawi there are currently matrilineal societies, in particular the Chewa group, where the husband moves to the wife's village, and widowers or divorced men are expected to return to their natal village and lose the appropriation rights to the land in their wife's village. However, the family's key decision-maker concerning farm management still remains the husband (Place and Otsuka 2001, Hansen et al. 2005, Takane 2008).

In Sumatra the lineage land, particularly that for paddy fields, has traditionally been owned collectively by a group of akin members, and this group usually consisted of a grandmother, her husband, children, and grandchildren. This land is customarily bequeathed from mothers to daughters according to the decision of the lineage head, who is normally the maternal uncle. The share tenancy also follows that rule. Women are the guardians of lineage land and can oppose the transfer of land to non-family members. Men typically cultivate their wives' lands or, if unmarried, they work as farm laborers or emigrate to other areas to accumulate savings or establish a trade. However, as in the Malawi case, it is primarily husbands who make farm management decisions, even though they have no customary land rights (Otsuka et al. 2001, Suyanto et al. 2001, Quisumbing and Otsuka 2001, Quisumbing et al. 2001).

The old Garos' inheritance system is the most biased towards women among traditional societies. Until the turn of the XIX century, they practiced matrilineal inheritance. Commons' use rights were tied to residence and men were supposed to move to their wife's village. Men could not inherit property under any circumstance, and self-acquired property of men belonged to the closest female ascendant or descendant or, if married, to their wives. This female-biased system could also be explained by the fact that women played a major role in crop production and the gathering of forest produce. ${ }^{26}$ However,

both the 8 villages and the entire valley. The coefficient of the dummy is significant at the $5 \%$ level. When removing the observations of the valley $(\mathrm{N}=16)$, the coefficient is significant at the $10 \%$ level.

${ }^{25}$ The other endogamy data are from Cogolo, Borgo Valsugana, Predazzo, Levico, Pergine, Rovereto, Moena, Forno.

${ }^{26}$ Similarly, Fleck and Hanssen (2009) found that the inheritance system on private land in the ancient Sparta mirrored work specialization. Sparta based its agricultural production on occupied land by means of captive labor force, thus men could specialize in military activities rather than in agricultural activities. It was desirable then to employ women on the management of land. However, women could fill this role more efficiently only if they were given appropriate incentives in terms of property rights, in other words they had the right to receive by inheritance and to bequeath the land. Thus, women enjoyed important inheritance rights during the Spartan regime. However, once occupied lands were lost and women's fertility rate diminished because of their increased opportunity costs while working, women's rights began to be restricted. 
although customary rules vested women with significant rights on land, the managerial control and the jural authority over land was vested in men (Agarwal 1994). ${ }^{27}$

(iii) The exogenous removal of the charters regime by Napoleon at the beginning of the XIX century brings about two considerations. First, unlike in modern states, within the charters regime each community had the right to locally establish and discretionally change inheritance rules on collective resources. This decentralized decision process might have locked the alpine communities in a patrilineal system. Consider for instance a community that decided on a possible transition from a patrilineal to an egalitarian inheritance system to improve the genetic health of the community. In some situations this change could have taken place if all other communities had been characterized by an egalitarian system but not if they were under a patrilineal system. The reason is that the costs in terms of per-capita collective wealth could have been much higher in the latter case. Hence, decentralized decisions on inheritance could have made it very difficult to switch from a patrilineal system to an egalitarian one. Second, this decentralized decision system was later replaced by a centralized government that did not allow local variations in inheritance rules. In Trentino, the Napoleon invasion of 1796 brought about an exogenous shock that soon put an end to the charters experience. It is difficult to assess whether this change improved the welfare of the region as a whole. In principle, it is possible that the centralized adoption of an inheritance system would be globally optimal. Besides the argument of genetic health, a universal egalitarian system could work as an insurance scheme against shocks hitting communities asymmetrically. In a long-run perspective, risk-averse individuals would prefer to live in a society without heavy costs of moving to other villages in case of exogenous shocks. However, as we have documented, with decisions decentralized at the community level an egalitarian inheritance system is likely to be evolutionarily unstable.

\section{Conclusions}

Over a period of six centuries, women in the Italian Alps gradually lost their property rights on the commons. This finding comes from a systematic study of inheritance systems on the commons in about three hundred villages between the $13^{\text {th }}$ and $19^{\text {th }}$ century. Thus, in the late medieval period women in the Alps had substantially more rights on collective properties than in the modern period.

We argue that this erosion in women's rights emerged as a protective measure to preserve the percapita endowment of collective properties within a community. Hence, there exist economic factors behind this institutional change. Egalitarian inheritance systems on the commons were evolutionarily unstable because they allowed immigration from outside through marriage, which threatened the community common resources. Members of richer communities could react to preserve their share of commons by introducing a gender-biased inheritance system. A patrilineal system contributed to keep community size stable by limiting net migration through marriage. The open question is why the Trentino communities selected a patrilineal over a matrilineal inheritance system on the commons. A

\footnotetext{
${ }^{27}$ Very few communities have adopted matrilineal inheritance systems. Sometimes the word matrilineal has been used with a different meaning, for instance in the case of the so-called uterine matrilineal systems in Western Ghana in which land is allocated to males and transferred intergenerationally to males; however this occurs through the members of the matriclan and women have access to land only through their husbands or fathers (Lastarria-Cornhiel 1997, Quisumbing et al. 2001, La Ferrara 2007).
} 
matrilineal system would have delivered the same consequences in terms of net migration. The communities may have preferred a patrilineal system because of social, cultural, or further economic reasons (e.g. Alesina et al. 2013) - a question that we leave for future investigation.

Discriminating women in property rights had deep impacts on the openness and endogamy levels of communities. For a given pattern of inheritance systems in the region, one can infer a level, direction, and type of migrations across communities. If all communities adopted an egalitarian system, one could expect a high level of internal migrations, going from the poor toward the rich communities in terms of per-capita collective wealth, and involving both men and women. If all communities adopted a patrilineal system, one could expect a low level of internal migrations, spread evenly across all communities, and involving mostly women. Over the long-term, introducing a gender-biased inheritance system to close the community to immigration generated a trade-off between preserving the per-capita collective wealth and undermining the variety in the community genetic pool. We observed a subset of Trentino communities and found that the level of endogamy in marriage steadily increased over the centuries, which may have weakened their genetic health.

At the regional level, this institutional change spread by contagion. Left alone under decentralized decision-making, communities engaged in a progressive closure towards outsiders. This process was characterized by path-dependency: the earlier decisions of some communities to change the inheritance system in favour of men effectively set the direction for the subsequent adjustments in other communities, leading the whole region toward a patrilineal system. If a community had switched to a matrilineal system in the middle of the process, that would not have been enough to steer the whole region toward a matrilineal system.

Once the process was completed, the communities were locked into a situation of women's discrimination and unable to move the region back to an egalitarian inheritance system. The lock-in effect springs from the decentralized decision-making over inheritance systems. In fact, a shift from a patrilineal to an egalitarian system could not have taken place through unilateral changes. Consider, as a thought experiment, an overnight decentralized change to an egalitarian system by all communities. This would not generate a new stable situation. On the contrary, it would trigger a decentralized process of adjustment toward a gender-biased system, either back to the patrilineal system or toward a matrilineal system. One way to restore gender equality would be to have a central state implementing a uniform egalitarian system on the whole region. After the Napoleonic invasion, a centralized state replaced the traditional political regime. Communities lost their autonomy of decision over the management of the commons and the local definition of property rights. An open question is about the role of a central state in ensuring gender equality in property rights.

In conclusion, the inheritance system on common resources turned out to be a cornerstone of a social and economic structure because of its consequences on migration patterns, genetic mixing, regional economic inequalities, population growth, and gender discrimination. The very long-term perspective of this study has allowed to capture the underground deep forces that shaped human societies over the centuries. 


\section{Bibliography}

Agarwal, B. (1994). A Field of One's Own: Gender and Land Rights in South Asia. Cambridge (UK): Cambridge University Press.

Alesina, A., Nunn, N., and Giuliano, P. (2013). "On the Origins of Gender Roles: Women and the Plough", The Quarterly Journal of Economics, 128(2): 469-530.

Alfani, G. (2011). "Le Partecipanze: il caso di Nonantola", in La gestione delle risorse collettive nell'Italia settentrionale (secoli XII-XVIII), Eds. G. Alfani e R. Rao, pp. 48-62. Milano: Franco Angeli.

Andreatta, G., and Pace, S. (1981). Trentino, autonomia e autogoverno locale. Trento: Saturnia.

Bellettini, A. (1987). La popolazione italiana: Un profilo storico. Torino: Einaudi.

Botticini, M., and Siow, A. (2003). “Why Dowries?”, American Economic Review, 93(4): 1385-98.

Casari, M. (2007). "Emergence of Endogenous Legal Institutions: Property Rights and Community Governance in the Italian Alps", The Journal of Economic History, 67, 191-226.

Casari, M., and Lisciandra, M. (2011). "L'evoluzione della trasmissione ereditaria delle risorse collettive in Trentino tra i secoli XIII e XIX", in La gestione delle risorse collettive nell'Italia settentrionale (secoli XII-XVIII), Eds. G. Alfani e R. Rao, pp. 17-31. Milano: Franco Angeli.

Casari, M., and Lisciandra, M. (2013). Gender discrimination and migrations: a model of inheritance on the commons, mimeo.

Chiocchetti, V., and Chiusole, P. (1965). Romanità e Medioevo nella Vallagarina. Rovereto: Manfrini Editori.

Cole, J.W., and Wolf, E.R. (1974). The Hidden Frontier: Ecology and Ethnicity in an Alpine Valley. New York: Academic Press.

Consiglio provinciale d'agricoltura pel Tirolo 1903-1904, Tabelle sulle condizioni agricole forestali economiche, Bollettino del Consiglio provinciale d'agricoltura.

Debiasi, L. (1953). "Contributo allo studio della popolazione del Trentino nel XVII secolo", in Studi e Ricerche Storiche sulla Regione Trentina, Eds. C.E.S. Trentino. Padova: Stediv.

De Moor, T. (2008). "The silent revolution: a new perspective on the emergence of commons, guilds, and other forms of corporate collective action in Western Europe", International Review of Social History, 53(S16): 179-212.

De Moor, T. (2009). “Avoiding Tragedies: a Flemish Common and Its Commoners under the Pressure of Social and Economic Change during the Eighteenth Century", The Economic History Review, 62(1): $1-22$. 
Engels, F. (1884). The Origin of the Family, Private Property and the State. Hottingen-Zurich.

Fiebiger, H. (1959). Bevölkerung und Wirtschaft Südtirols: eine Darstellung ihrer Situation und ihrer Probleme. Bergisch Gladbach: Heider.

Fleck, R.K., and, Hanssen, F.A. (2012). “'Rulers ruled by women': an economic analysis of the rise and fall of women's rights in ancient Sparta", Economics of Governance, 10(3): 221-245

Franceschini, I. (2009). "Uomini e territorio a Pinè tra XV e XVIII secolo". In Storia di Piné: Dalle origini alla seconda metà del XX secolo, Eds. M. Bettotti, pp. 223-334. Baselga di Piné (TN): Comune di Baselga.

Hansen, J.D, Luckert, M.K., Minae, S., and Place, F. (2005). "Tree Planting under Customary Tenure Systems in Malawi: Impacts of Marriage and Inheritance Patterns", Agricultural Systems, 84(1): 99118.

Hardin, G. (1968). “The Tragedy of the Commons”, Science (AAAS), 162 (3859): 1243-1248.

Inama, V. (1931). Fondo e la sua storia. Rovereto (TN): Mercurio

La Ferrara, E. (2007) "Descent Rules and Strategic Transfers. Evidence from Matrilineal Groups in Ghana”, Journal of Development Economics, 83, 280-301.

Lastarria-Cornhiel, S. (1997). "Impact of Privatization on Gender and Property Rights in Africa", World Development, 25(8): 1317-33.

Malanima, P. (2002). L'economia Italiana - Dalla crescita medievale alla crescita contemporanea. Collana "Le vie della Civiltà", Bologna: Il Mulino.

Motta, L. (1978). Aspetti di storia economica e demografica di una valle del Trentino: la Valle del Fersina, Laurea thesis, University of Bologna, Department of Literature and Philosophy.

Netting, R. McC. (1981). Balancing on an Alp, Ecological Change and Continuity in a Swiss Mountain Community. Cambridge: Cambridge University Press.

Ostrom, E. (1990). Governing the Commons: the Evolution of Institutions for Collective Action. Cambridge: Cambridge University Press.

Otsuka, K., Suyanto, S., Sonobe, T., Tomich, T.P. (2001). "Evolution of Land Tenure Institutions and Development of Agroforestry: Evidence from Customary Land Areas of Sumatra", Agricultural Economics, 25: 85-101.

Place, F., and Otsuka, K. (2001). "Tenure, Agricultural Investment, and Productivity in the Customary Tenure Sector of Malawi”, Economic Development and Cultural Change, 50(1): 77-100.

Quisumbing, A.R., and Otsuka, K. (2001). "Land Inheritance and Schooling in Matrilineal Societies: Evidence from Sumatra", World Development, 29(12): 2093-2110. 
Quisumbing, A.R., Otsuka, K., Suyanto, S., Aidoo, J.B., and Payongayong, E. (2001). "Land, Trees, and Women: Evolution of Land Tenure Institutions in Western Ghana and Sumatra", IFPRI Research Report 121.

Sartori-Montecroce, T. (2002). La comunità di Fiemme e il suo diritto statutario. Cavalese (TN): Magnifica comunità di Fiemme.

Suyanto, T., Tomich P., and Otsuka, K. (2001). "Agroforestry Management in Sumatra", in Land Tenure and Natural Resource Management, a Comparative Study of Agrarian Communities in Asia and Africa, Eds. K. Otsuka and F. Place, pp. 97-143. Washington D.C.: The International Food Policy Research Institute.

Takane, T. (2008). "Customary Land Tenure, Inheritance Rules, and Smallholder Farmers in Malawi", Journal of Southern African Studies, 34(2): 269-291.

Wopfner, H. (1954). Bergbauernbuch: von Arbeit und Leben des Tiroler Bergbauern in Vervangenheit und Gegenwart, Innsbruck: Wagner.

\section{Archives}

AST (Archivio di Stato di Trento - Trento Archive), lat. sect., C.12, f. 69 and 72. 


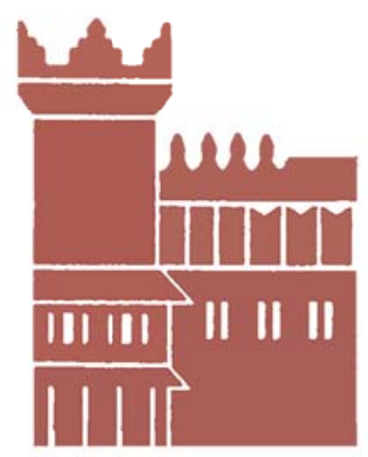

Alma Mater Studiorum - Università di Bologna DEPARTMENT OF ECONOMICS

Strada Maggiore 45

40125 Bologna - Italy

Tel. +39051 2092604

Fax +390512092664

http://www.dse.unibo.it 